\title{
EFFECTS OF LABOUR MIGRATION ON POVERTY AND AGRICULTURAL GROWTH IN NEPAL
}

\author{
Krishna P. Pant ${ }^{1}$
}

\begin{abstract}
Increasing labour shortage in agriculture sector and contribution of remittance on poverty reduction has raised the importance of studies on employment, poverty and agricultural growth nexus. The study explores the effects of foreign employment on poverty and agricultural growth. The study using time series secondary data for 19 years fitted econometric models at sectoral level to establish the effects of migration on poverty and agricultural production. It also compares agricultural output elasticity of foreign employment and assesses the role of foreign employment on the relationships between growth, poverty and agricultural development. The results show that migration decreases poverty and at the same time decreases agriculture production. But, the decrease in agriculture gross domestic product per unit of labour migrated is smaller than the per capita remittance. The study does not dwell on the social and cultural effects of the labour migration. The results will be useful for decision makers to devise sound policies on migration, poverty and agricultural development.
\end{abstract}

Key words: agriculture growth, employment, migration, poverty.

\section{INTRODUCTION}

\section{BACKGROUND}

Agriculture is the major source of livelihood for the rural poor. Of the 1.1 billion workers active in agricultural production worldwide, nearly a half of them are in wage labour (ILO, 1996a) and are poor. Governments in many developing countries are emphasizing poverty reduction through economic growth and agricultural production. Poverty reduction has received increased focus in development debate in the past two decades and progress on poverty reduction has become a major measure of success of development policy (Aigbokhan and Alli, 2008). Islam (2004) reports that the most of the poor in developing countries do work, but in low productive, low-paying jobs, where they cannot earn enough to raise themselves above the poverty threshold. Agricultural wage workers consistently display the highest incidence of extreme poverty, largely because of the low wages on small farms and seasonal unemployment. Shift of agriculture labour to non-agriculture sector, especially to foreign employment is attributed to poverty reduction (CBS, 2004). Of the approximately 1.1 billion workers active in agricultural production worldwide, nearly half are in wage labour and are poorest of the poor (ILO, 1996b). In South Asia, over $87 \%$ of the work force is earning less

${ }^{1}$ Chief, Market Research and Statistics Management Programme, Department of Agriculture, Lalitpur, Nepal. Email: kppant@gmail.com 
than \$2 a day, even though the region has experienced strong productivity and gross domestic product (GDP) growth rates indicating that many jobs, particularly in the agricultural sector, are still low productive and pay low wages (UN, 2005). Extreme poverty among workers in developing countries is often associated with subsistence activities - for example, contributing family workers operating in small-scale agricultural work (Kapsos and Horne, 2011). Studies suggest that countries that made noticeable progress on poverty reduction were those with higher growth rates (World Bank, 2000; Dollar and Kraay, 2001). Osmani (2004) demonstrates that sustained and rapid economic growth has invariably been accompanied by reduction of poverty and, conversely, persistent growth failures have invariably been accompanied by persistent failure to reduce poverty. Raising the rate of growth is thus being increasingly recognized as necessary for poverty reduction (UNDP, 2003a; Osmani et al., 2003; McKinley et al., 2003; Weeks et al., 2003; UNDP, 2003b; Rahman and Islam, 2003 and Islam, 2002). But, some others opine that the growth is not enough for poverty reduction as there are changes in the structure of growth (Ravallion and Datt, 1996; Mellor, 1999). In economies with high income inequality, the growth in economy is not enough for poverty reduction and in many African countries rising inequality is reported in spite of a decade long efforts on poverty reduction (Cornia and Kiiski, 2001). Nigeria achieved economic growth but the poverty incidence increased from $42.7 \%$ in 1992 to $54.4 \%$ in 2004 (Aigbokhan and Alli, 2008). Among the poorest $40 \%$ of the population in Nepal, 15\% of working men are engaged in unskilled nonagricultural wage employment and 13 in agricultural wage employment (CBS, 2006b).

Migration and foreign employment generates financial and human capital which, if leveraged for development, can help reduce poverty. Adams (2003) reports that a $10 \%$ increases in the share of international migrants in a country's population reduces the share of people living in poverty $(\$ 1.00 /$ person/day) by $1.9 \%$. Before developing strategies that can help people benefit more from the migration that is already taking place, it is important to understand more about the process, the way it affects and is used by society, and the flows of remittances (Hoermann et al., 2010). Agriculture in South Asia has become a source of labour force for foreign employment particularly to East Asian Countries, Gulf Countries and North America. Increased foreign employment opportunities in a decade of time have decreased the labour force in agriculture. Effects of this exodus of labour force to the agriculture productivity have not been adequately studied. The returnees from foreign employment are being repatriated to the agriculture sector. Thus, agriculture is also a cushion for the labour force expelled from other sectors.

\section{PROBLEM STATEMENT}

In a country with 26.6 million population growing at the rate of $1.44 \%$ per annum, every year an additional 383,000 individuals are expected enter to the labor market in Nepal (CBS 2012). Due to political instability, after effects of armed conflict, stringent labour law and poor investment climate, creation of employment opportunities is very limited in the country. The economy is in transition, governments are not stable, extortions and other crimes are commonly reported by the media, labour law does not permit hire and fire policy, industrial 
safety is weak leading to limited opportunities of employment creation. Some of the labour force, with increasing trend, targets for foreign employment. Though the government has opened 109 countries for foreign employment ${ }^{1}$, over $93 \%$ of the migration is destined only to four countries, namely Malaysia, Qatar, Saudi Arabia and United Arab Emirates.

The migration plays a major role in Nepalese economy with 1.6 million people (5.9\% of the population) working abroad (Riester, 2010). The money sent back by the longer term (more than six months) migrants to their families back home is considered as a remittance. The money brought back by the seasonal migrants (being abroad for six months or less) is counted as the current transfer. Thus, the large part of the labour earnings from India falls under the current transfer and not remittance. The current transfer is belied to ease the life supplementing the consumption need and contribute to reduce poverty. The remittances are believed to reduce poverty. It is reported that a $10 \%$ increase in the share of remittances in a country's GDP can lead to a 1.2\% decline in poverty (Adams and Page, 2005). Though the remittance primarily contributes to the household income it helps the society by increased demand for consumption goods and services. CBS (2006b) reports that the poverty would have declined by $7.1 \%$ points instead of the observed $11 \%$ points if the incidence of remittances had remained unchanged between 1995-96 and 2003-04.

Very scanty literatures are available on the effects of foreign employment in the domestic economy, particularly in agriculture. Pant (2008) argues that the remittances can generate a positive effect on the economy through various channels such as savings, investment, growth, consumption, and poverty and income distribution. Similarly, remittances also contribute significantly to GDP and to stability of the economy by lowering the probability of current account reversals (Pant 2008). It also create multiplier effects in the domestic economy, by producing employment opportunities and spurring new economic and social infrastructure and services, specially where effective structures and institutions have been set up to pool and direct remittances. However, some studies also pointed out some deleterious impacts of remittances on national economic growth in the medium and longer term (Pant 2008). Some studies estimate that on an average, a $10 \%$ increase in the number of international migrants in a country's population can lead to a $1.6 \%$ decline in poverty headcount ${ }^{2}$. Same report also says that a $10 \%$ increase in the share of remittance in a country's GDP can lead to a $1.2 \%$ decline in poverty.

\section{OBJECTIVES}

Increasing labour shortage in agriculture sector has raised the importance of studies on employment and poverty growth nexus. The main objective of the study is to understand the effects of foreign employment on poverty and agricultural growth. The specific objectives are to compare the experience of agricultural

\footnotetext{
1http://www.dofe.gov.np

${ }^{2}$ http: //siteresources.worldbank.org/INTPROSPECTS/Resources/334934-1110315015165/MD Brief8.pdf.
} 
growth and poverty in relation to foreign employment; to explore growthemployment-poverty nexus in agriculture sector; to estimate and compare the role of foreign employment on the relationships between growth, poverty and agricultural development.

\section{METHODOLOGY}

The study explored the effects of labour migration on agricultural production and poverty using secondary data. It assessed growth-employment-poverty nexus and estimated employment elasticity of agriculture output. The growth-employmentpoverty nexus can be assessed using a simple correlation analysis in which the correlation between growth and employment, growth and poverty, and employment and poverty; and this nexus can also be assessed by estimating growth elasticity of poverty (Ravallion, 2001; Aigbokhan and Alli 2008). To quantify the employment linkage to the poverty, the output elasticity of employment (OEE) is estimated in agriculture sector. This captures the effects of change in wage employment and change in self-employment opportunities and time series estimates are far better indicators of employment intensity of growth (Khan, 2007). The elasticity shows the ratio of observed proportionate change in employment to observed proportionate change in output over a period of time.

The sources of data were Economic Survey, Statistical Information on Nepalese Agriculture, Statistical Handbook, and records of foreign employment of Department of Foreign Employment. Time series data on gross domestic production, agricultural gross output, agriculture employment, foreign employment, public expenditure in agriculture, investment in the agriculture and poverty head count ratio were obtained from secondary sources like Economic Survey, statistical handbooks and publications of the central banks. Following macro-economic models were estimated.

$$
\begin{aligned}
& A G D P=\beta_{0}+\beta_{1} E_{f}+\beta_{2} E_{a}+\beta_{3} P_{a}+\beta_{4} l_{a}+\beta_{5} D+\beta_{6} L+z \\
& P H C=\beta_{0}+\beta_{1} E_{f}+\beta_{2} E_{a}+\beta_{a} P_{a}+\beta_{4} I_{a}+\beta_{5} D+\beta_{6} L+\varepsilon
\end{aligned}
$$

In which, AGDP is Agricultural Gross Domestic Production, PHC is Poverty Headcount ratio, $E_{f}$ is foreign employment as percent to the total labour force, $E_{a}$ is labour availability in agriculture as percent to the total labour force, $P_{a}$ is public expenditure in agriculture per unit of agriculture labour, $\mathrm{I}_{\mathrm{a}}$ is investment in agriculture per unit of agriculture labour, D is dependency ratio (non-labour population divided by the labour force), $\mathrm{L}$ is adult literacy rate and $\varepsilon$ the error term.

Since the foreign employment is expected to influences the income of the poor, employment in the agriculture and foreign countries have been used as explanatory variables. Likewise, dependency ratio has been used as an indicator of the extent of labour force participation with an expectation of lower production due to higher dependency ratio. Level of education of the workforce is 
hypothesized as exerting a positive impact on the income of the poor and reducing the poverty headcount ratio. However, at the macro level it was not easy to define this variable; and hence a surrogate in the form of adult literacy rate has been used as an indicator of the education variable. For developing the linkages between the growth and poverty, the estimates of equation (1) and equation (2) are compared.

\section{RESULTS}

\section{LABOUR MIGRATION}

The growth of the labour migration follows a quadratic function with positive coefficients of the second degree and negative of the first degree (Figure 1). The growth of migration is quite steep. The first steepness of the migration during 2004/05 to 2007/08 can be attributed to heightened domestic armed conflict. The decrease of migration during the year 2008/09 may be due to two forces. First, at the domestic level there was peace agreement that increased hope of peace in the society that attenuating the push force. Second, at the same time financial crisis at the destination countries weakened the pull force for labour migration. After 2009 the migration is increasing again very fast. This can be attributed to political instability in the country.

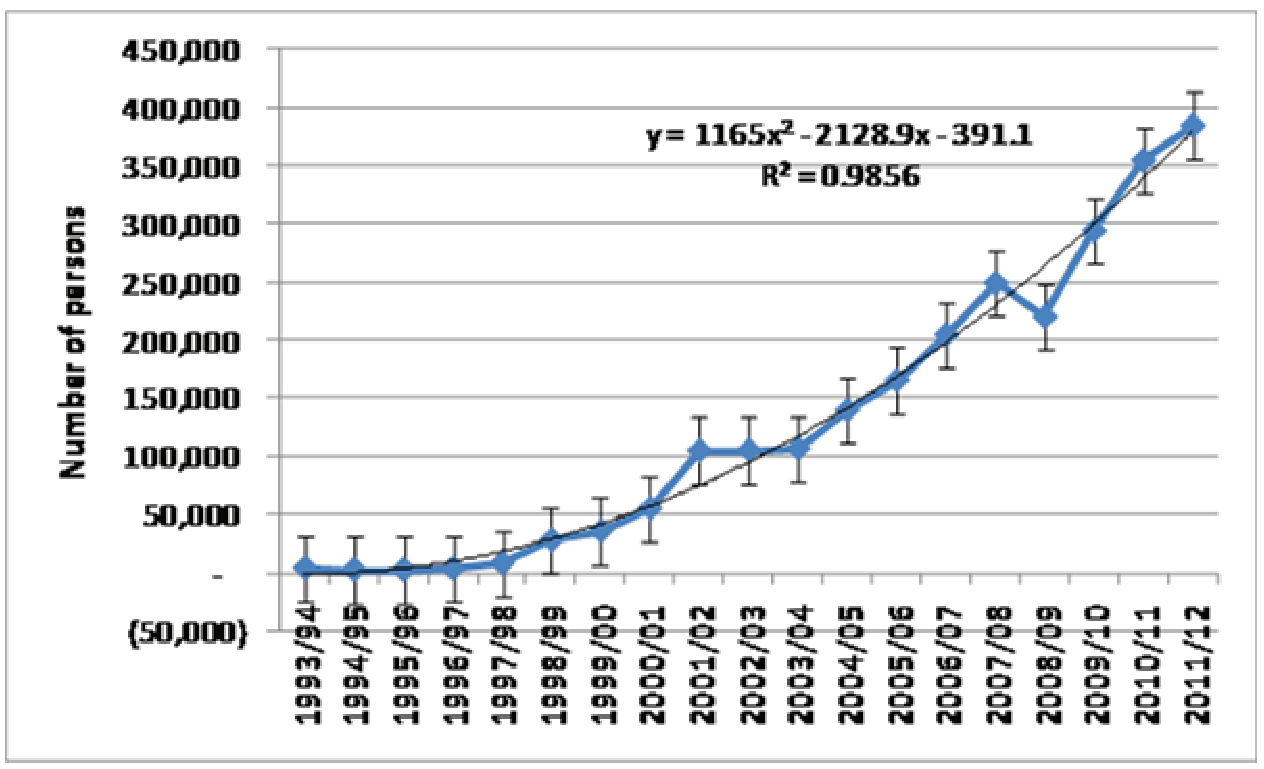

Figure 1. Emigration for overseas employment

In aggregate, 2,465,699 people have gone to different countries for foreign employment by July 2012. In addition, the number of labour migration through unauthorized routes is also assumed to be significant (MOF, 2010). Labour 
migration to India does not come to the national figure. The flow of labour out migration follow seasonal pattern. The flow is lowest during the festival season of October and marriage season of March. The seasonal pattern is not affected by crop planting and harvesting seasons of the agriculture.

The major destinations of the Nepalese labour force are Malaysia, Qatar, Saudi Arabia and United Arab Emirates. These four countries absorb nearly $90 \%$ of the labour force migrated from Nepal (Figure 2). In year 2010/11, $32.0 \%$ of the labour force has gone to Malaysia followed by Qatar (21\%) and Saudi Arabia (21\%). Similarly, 15\%went to United Arab Emirates (UAE), \&\%to Kuwait and 2\% to Bahrain. The migration to South Korea includes those sent under the employment permit system (EPS). The size of unauthorized migration can be guessed from the news that around 30,000 Nepalese workers have managed to enter and work in Iraq in spite of the ban by Nepalese government. In addition, a large number of unskilled labourers migrate every year to India, but the migration statistics do not include this figure. It is not possible to record the movement of labourers from Nepal to India and vice versa due to porous border and free transit between India and Nepal. As they have no visa requirements, their movements are not registered anywhere. Apart from approximately 0.25 million employed in Indian army, it is generally poorer Nepalese migrants who move to neighboring India (Seddon, 2005). India is a major destination for very poor labourers who cannot afford for abroad travel, particularly those from the far western hill areas of the country.

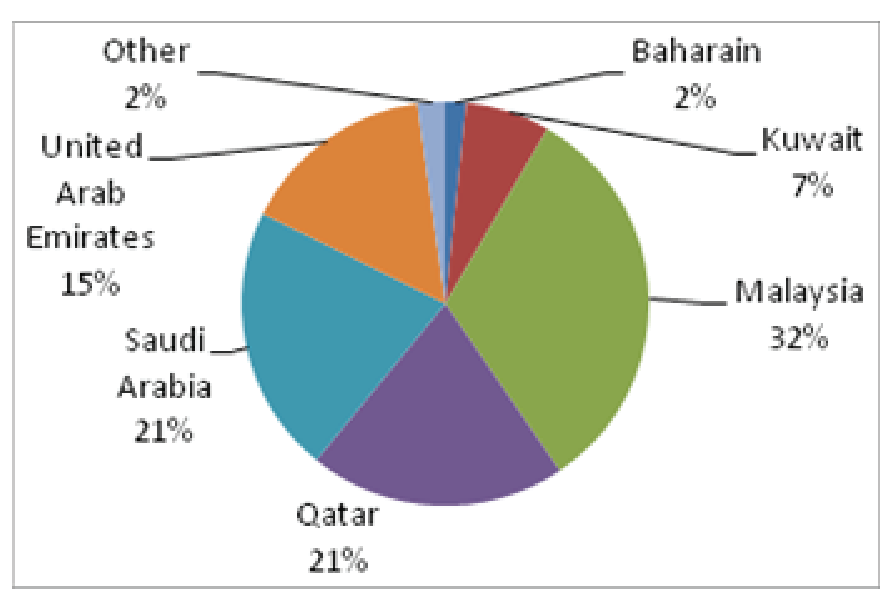

Source: Data from Foreign Employment Department, Government of Nepal

Figure 2. Labour migration by destinations (2010/11)
Nepal Labour Force Survey (2008) reports that the labour force participation rate is $83.4 \%$, rate of employment $97.9 \%$, and the economically active population 83.0\% (CBS, 2009). Out of those employed, $16.9 \%$ are engaged in formal salaried/wage earning activities, while the remaining $83.1 \%$ are self-employed (MOF, 2010). Of the total employed $73.9 \%$ are employed in the agriculture sector (Table 1). The agriculture is still a major source of the employment in the country. Only two-thirds of the labour force is fully employed and the problem of disguised unemployment is very high. Since there is no unemployment benefits in the country no authentic data is available for unemployed. 
Table 1. Labour force participation in Nepal

\begin{tabular}{|c|c|c|c|c|c|}
\hline & \multicolumn{2}{|l|}{ Major indicators } & $\%$ & (2009) & \\
\hline 1 & \multicolumn{2}{|c|}{ Labour force participation rate } & 83.4 & eholds & \\
\hline 2 & \multicolumn{2}{|c|}{ Economically Active Population Rate } & 83.0 & ttance or cu & rent \\
\hline 3 & \multicolumn{2}{|c|}{ Employment Rate } & 97.9 & holds rec & \\
\hline 4 & \multicolumn{2}{|c|}{ Employment Growth Rate } & 2.45 & mittance & \\
\hline 5 & \multicolumn{2}{|c|}{ Population Employed in the formal sector } & 16.9 & After the do & hestic \\
\hline 6 & \multicolumn{2}{|c|}{ Self Employed Population } & 83.1 & per of the re & nittar \\
\hline 7 & \multicolumn{2}{|c|}{ Population Engaged in Agriculture Sector } & 73.9 & India but & \\
\hline 8 & \multicolumn{2}{|c|}{ Fully Employed Population } & 66.8 & gh the num & \\
\hline \multicolumn{3}{|c|}{ Source: CBS 2009.} & & ibution of & \\
\hline & $\begin{array}{l}\text { Source of } \\
\text { remittance }\end{array}$ & $\begin{array}{l}\text { Number of remittance } \\
\text { (in a year) }\end{array}$ & $\begin{array}{l}\text { Average size of } \\
\text { remittance (NRs } \\
\text { 1000) }\end{array}$ & $\begin{array}{l}\text { Total amount of } \\
\text { remittance } \\
\text { (NRs billion) }\end{array}$ & $\%$ \\
\hline 1 & Within Nepal & 2,232 & 22.83 & 16.00 & 16.8 \\
\hline 2 & India & 1,253 & 22.04 & 10.57 & 11.1 \\
\hline 3 & Malaysia & 480 & 85.14 & 15.16 & 15.9 \\
\hline 4 & Saudi Arabia & 386 & 90.87 & 11.81 & 12.4 \\
\hline 5 & Qatar & 522 & 90.94 & 16.85 & 17.7 \\
\hline 6 & United Kingdom & 49 & 235.06 & 1.76 & 1.8 \\
\hline 7 & Other & 648 & 146.05 & 22.76 & 23.9 \\
\hline 8 & Do not know & 42 & 29.60 & 0.24 & 0.3 \\
\hline & Total & 5612 & 51.56 & 95.16 & 100 \\
\hline
\end{tabular}

Source: CBS (2009) National Labour Force Survey 2008, page 172.

Large chunk of the labour force is migrated to low wage countries. The migration to high wage countries like Japan, North America and Germany is very limited. It clearly shows that the labour force is unable to move to the high wage countries of Europe and America. The expectation of the earning is also not much high.

\section{EFFECTS OF FOREIGN EMPLOYMENT ON POVERTY}

There are claims that the foreign employment reduces poverty. Logically as the migration is taking place voluntarily, the migrating people, if they have full information of the costs and benefits of migration, must have chosen the option better for them. It means, the migration has created option to the labourers and they must have been better off from it. 
Remittances by international migrants to Nepal have grown dramatically in recent years and are now the largest source of external finance. During the year 2008/09 the remittance income was NRs 209.7 billions which increase to NRs 330.9 in $2011 / 12$. In recent years it is growing by nearly $50 \%$ per annum (Figure 3 ). The growth in the remittance is due to the rise in the number of migrants than the increase in the wage rate. The compound growth rate of the remittance at current price $(21.20 \%)$ is much smaller than that of the migration $(33.52 \%)$. It means the remittance per head of the migrant has gone down even in the current price.

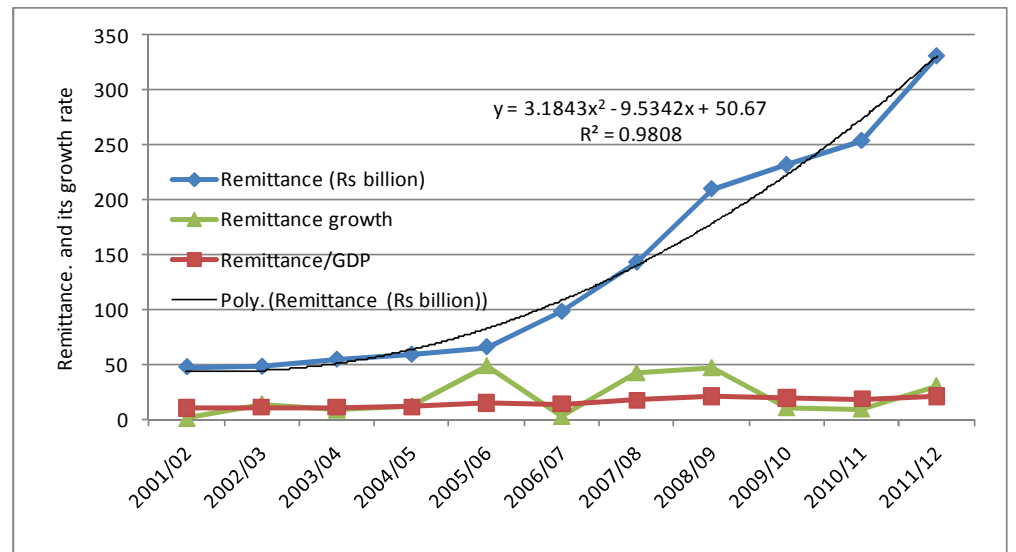

Source: Data obtained from Ministry of Finance (2012): Economic Survey, Fiscal year 20011/12.

Figure 3. Remittance and its contribution to the economy

The growth in remittance follows a quadratic function. The growth rate of remittance to GDP ratio is increasing by an annual compound growth rate of 9.97\%. This amount, however, does not include the unofficial transfers, which is estimated to be $50 \%$ or higher of the officially recorded flows (Pant, 2008). Some other literatures estimate the informal flow as high as $69 \%$ of foreign remittance (in 2008) ${ }^{1}$. The main informal flow is through 'hundi' ${ }^{2}$. It is an unconditional order in writing made by a person in foreign country directing another person at home to pay a certain sum of money to a person named in the order. Another system of money transfer is the movement of the natural persons carrying the cash to hand it over to the relatives of the sender in Nepal.

It is hypothesized based on the literature that the foreign employment and remittance thereof reduces poverty. The logic behind it is that poor works as the labourer and the remittance goes directly to the poor household. The role of remittances in the economy and poverty reduction was claimed first by the Nepal Living Standards Survey (2004). It showed that the poverty declined from $42 \%$ in $1995 / 96$ to $31 \%$ in $2003 / 04$ and to $25 \%$ in 2011 . This decline is attributed the decline to the increasing flow of the remittances. During this period, nothing such spectacular happened in the country to attribute this poverty reduction.

\footnotetext{
1http://www.mof.gov.np/monitoring/publication/NewsandViews.pdf

${ }^{2}$ The hundi refers to informal financial instruments used in credit transactions and remittances for the purpose of transfer of funds from one place to another.
} 
Investment, employment and economy were not growing during that period due to the armed conflict in the country.

There are several multiplier effects of remittances. The labour migration also created off farm employment within the country. The government has established Department of Foreign Employment and Foreign Employment Promotion Board. By July 2012, the Department of Foreign Employment has registered 994 manpower companies and 54 foreign employment orientation companies in the country. These companies employ many people directly and engage large number of agents on commission basis. Many of the companies (78) have branches in other parts of the country. Some others are getting employment in providing medical testing services. The remittance flow also flourished money transfer companies and their agents in the country. Many other people are employed in institutions created for providing training to the aspirant migrants. The study however, does not include the creation of the domestic employment and their income. The Foreign Employment Act (2008) safeguards the rights and interests of workers by making it a safe, well managed, and dignified profession. Foreign Employment Department is established on 31 December 2008 under the Ministry of Labour and Transport Management to look after foreign employment related activities. The Department attempts curbs foreign employment related frauds and ensures that contracts are enforced. Such frauds and malpractices are different area for the study and not covered in this report.

The effects of migration and remittance flow on poverty are explored empirically. Descriptive statistics of the variables used in the econometric model are presented in Table 3. For time series comparison with suitable base, all the monetary variables are deflated to $1995 / 96$ price using overall urban consumers' price index. As the market for agricultural products are urban centers, price in the urban areas are the pull forces of agricultural products and more relevant for deflating the monetary values over the year. The average annual remittance for the year $1990 / 91$ to $2008 / 09$ is NRs 233 millions in 1995/96 price. During the same period, the deflated value of agriculture expenditure per agriculture labour is NRs 311 per annum. The agricultural credit disbursed by Agriculture Development Bank Limited per labour is NRs 784 per annum. Data on agriculture credit provided by other sources are not available. The agricultural land is 0.45 ha per labour, which decreased from 0.48 ha to 0.41 ha per labour. The average poverty head count ratio that was $49 \%$ in $1990 / 91$ decreased to $24.70 \%$ in $2008 / 09$ and the average for the study period is $36.46 \%$. The average agriculture gross output is NRs 21,545 per labour in 1995/96 price. It is not changing much over the years. Average annual migration is 75,380 persons. In the fiscal year 1990/91 it was only 363 and over the 19 years it increased to 249,051 per year. These variables are used for modeling the effects of migration on poverty and agricultural production.

The results of OLS estimation (Table 4) show that remittance decreases the poverty head count significantly. Per million rupees increase in the remittance flow decreases the poverty head count by $0.007 \%$. Another strong variable that is

\footnotetext{
${ }^{1}$ The poverty headcount itself is measured in percentage term.
} 
instrumental to poverty reduction is agricultural credit. Per rupee increase in per labour agricultural credit decreases the poverty headcount by $0.02 \%$. However, the agricultural expenditure unexpectedly increases the poverty. It is clear that the agricultural expenditure is not able to reduce poverty in the country. The function estimated explains over $98 \%$ of the variations in the poverty head count.

Table 3. Descriptive statistics of the variables used in the econometric models

\begin{tabular}{|c|c|c|c|c|c|c|c|}
\hline SN & Variable & Unit & $\mathrm{n}$ & Mean & Std. Dev. & Minimum & Maximum \\
\hline 1 & Remittance & NRs million & 19 & 233.90 & 263.48 & 32.00 & 856.71 \\
\hline 2 & $\begin{array}{l}\text { Agricultural } \\
\text { expenditure }\end{array}$ & NRs/labour & 19 & 311.54 & 93.94 & 187.30 & 476.01 \\
\hline 3 & Agricultural credit & NRs/labour & 19 & 784.15 & 286.82 & 305.78 & 1247.61 \\
\hline 4 & Cultivated land & Ha/labour & 19 & 0.45 & 0.02 & 0.41 & 0.48 \\
\hline 5 & $\begin{array}{l}\text { Poverty head } \\
\text { count }\end{array}$ & $\%$ & 19 & 36.46 & 7.61 & 24.70 & 49.00 \\
\hline 6 & $\begin{array}{l}\text { Agriculture gross } \\
\text { output }\end{array}$ & NRs/labour & 19 & 21545.49 & 1154.57 & 19649.28 & 23493.16 \\
\hline 7 & Migration & Person & 19 & 75380.24 & 84865.93 & 361.00 & 249051.00 \\
\hline 8 & Agriculture labour & Person & 19 & $6,602,642$ & 517808.40 & $5,961,788$ & $7,535,000$ \\
\hline
\end{tabular}

Note: All the monetary variables are deflated by overall urban consumer price index to 1995/96 price

Table 4. Effect of labor migration on poverty head count

\begin{tabular}{llll}
\cline { 2 - 4 } 1 & Variable & Coefficient & Standard Error \\
\cline { 2 - 4 } 2 & Remittance & $-0.007^{* * *}$ & 0.002 \\
3 & Agricultural expenditure per labor & $0.012^{* * *}$ & 0.003 \\
4 & Agricultural credit per labor & $-0.020^{* * *}$ & 0.002 \\
5 & Constivated land per labor & -29.239 & 20.822 \\
\cline { 2 - 3 } & $63.010^{* * *}$ & 9.611 \\
\hline
\end{tabular}

$\mathrm{F}(4,14)=280.32, \mathrm{n}=19$, Adjusted $\mathrm{R}^{2}=0.984$, Root $M S E=0.959$

Note: Dependent variable: Poverty headcount ratio. ${ }^{* * *}$ indicates significant at $1 \%$ level of significance.

Robustness of the specification was tested. Omitted variables of the model and heteroskedasticity of the study variable were tested. Ramsey RESET test using powers of the fitted values of poverty headcount is not significant at $5 \%$ level of significance $[F(3,11)=3.46$ and Prob $>F=0.055]$. The model is not having an omitted variable. Similarly, Breusch-Pagan/Cook-Weisberg test for heteroskedasticity test is not significant [chi2(1) $=0.22$ and Prob $>$ chi2 $=0.638]$. The study variable has a constant variance.

The poverty elasticity of the remittance is -0.04 . It is clear that the remittance reduces the poverty. The benefits of remittances are not limited to recipient households, but have a wider impact on the receiving society as remittances are spent, generating demand and jobs for local workers (Hoermann et al., 2010). Remittances increases consumption among the family members and provide insurance to crop failure and other natural calamities at home. The migrants also bring back some new skills. A few examples are that migrants from eastern Nepal to Darjiling brought skills on tea farming and migrants returned from Myanmar 
brought skills dairy cattle farming. But, many migrants rarely find suitable environment to use the skill they learnt to gainful activities. The coefficient for public agricultural expenditure is positive and significant. It means the public expenditure in agriculture is not instrumental in reducing poverty.

\section{EFFECTS OF FOREIGN EMPLOYMENT ON AGRICULTURAL PRODUCTION}

Large proportion of the agricultural labour force is seasonally employed. In the most part of the country, the agriculture is largely subsistence generating livelihood insufficiently. Nepalese agriculture is characterized by small ( $0.79 \mathrm{ha})$ and fragmented (3.6 parcels) landholdings with large proportion $(46 \%)$ of nonirrigated land (CBS 2006a; Government of Nepal 2011). Low level of technology limits the crop and livestock yields. People traditionally migrate seasonally to nearby countries to supplement their family income. Recently, with the access of labour force to higher wage foreign countries better off people also migrate overseas for better income and for experiences of being in foreign countries. Literature is not clear how the migration does affect the agricultural production in the country. As most of the labour force that migrates comes from agriculture (though no dissegrated data are available), the migration reduces the labour supply in agriculture. At the initial period when the surplus labour comes out of the agriculture, the productivity of the remaining labour force increases and the agricultural production does not decrease, thereby increasing the marginal productivity of the remaining labour. However, over a period if the labour migration continuously increases, the agriculture sector faces labour shortage thereby decreasing the agricultural production. It is hypothesized that the increasing labour migration after certain limit decreases the agriculture production in the country. As the AGDP does not include the intermediate consumption share of which is increasing due to increase in livestock and poultry production, the hypothesis is tested using agricultural gross output as an indicator variable to the agricultural production.

The OLS results (Table 5) show that the migration reduces agricultural gross output. More precisely, one labourer migrated reduces agricultural gross output by NRs 18,000 . Though this is much smaller amount as compared to the expected earning from the foreign employment, this result contradicts with the common believe that labour out migration from agriculture increases the productivity of the remaining labour force and maintain the production level.

Among the other confounding factors, the agricultural credit is found to increase the gross agricultural output. One rupee increase in agricultural credit increases the agricultural gross output by NRs 6.00 . Similarly, larger, the cultivated land per labour, smaller is the gross output per labour. This clearly shows that the land is facing a problem of labour shortage. However, as is the case of poverty, the agricultural expenditure per labour is not doing a favorable job in the economy. This is because of either the inefficiency of the public agricultural expenditure or because it does not generally results into the output during the same year. The equation thus estimated explains about $85 \%$ of the variations in agricultural gross output. 
The function estimated has omitted neither variable nor a problem of heteroskedasticity. Ramsey RESET test using powers of the fitted values of deflated agricultural gross output per labour was not significant $[F(3,11)=0.13$ and Prob $>F=0.943]$. Hence the model has no omitted variables. Breusch-Pagan / Cook-Weisberg test for heteroskedasticity test was not significant [chi2(1) $=0.01$ and Prob > chi2 $=0.906]$. The study variable was having constant variance.

Table 5. Effects of emigration on agricultural gross output

\begin{tabular}{llll}
\hline & Variable & Coefficient & Std. Err. \\
\hline 1 & Labour migration & $-0.018^{* *}$ & 0.006 \\
2 & Agricultural expenditure per labor & $-3.025^{*}$ & 1.434 \\
& & $6.003^{\star * *}$ & 1.417 \\
3 & Agricultural credit per labor & $-37900.230^{* *}$ & 13857.200 \\
4 & Cultivated land per labor & $36090.040^{* * *}$ & 5869.403 \\
5 & Constant &
\end{tabular}

$\mathrm{F}(4,14)=25.68^{* * *}, \mathrm{n}=19$, Adjusted $\mathrm{R}^{2}=0.846, \quad$ Root $\mathrm{MSE}=453.41$

Note: Agricultural gross output, agricultural expenditure, and agriculture credit are in NRs million per labor in 1995/96 price.

The analyses show that the labour migration though brings remittance in term of foreign currency making the balance of payment situation of the country better and reduces poverty, it decreases the agricultural production within the country. This makes the country more dependent on imported food products increasing vulnerability to fluctuations in international food markets.

\section{FUTURE PROSPECTS OF FOREIGN EMPLOYMENT AND RELATION TO POVERTY}

Increasing work force in the country continues to look abroad for the chance of gainful employment to make a better living. These labour outflows are likely to grow further in the years ahead. With the labour migration setting to rise in the coming years because of globalization, remittances can be expected to grow steadily but it may have mixed implications to the economy. Domestic labour shortage may harm the production, particularly the labour intensive production like agriculture. Increased remittance will increase the demand for goods and services within the country. The foreign employment has already helped for expansion of telephone and banking or money transfer networks in village areas for calling to foreign country and for receiving remittance. Decrease in domestic production due to labour shortage will increase the import. Larger the share of import on domestic consumption, larger will be the effects of international price shocks. The shocks on the food products will adversely affect the poor who have no access to foreign employment due to economic or other reasons. To overcome such effects on the domestically bound poor labour force, the wage rate back home should increase. It is expected that when domestic production units face labour shortages, the wage rate will increase. However, this increase in the wage depends on the labour productivity. If the labour productivity cannot increase an an increase in the wage rate, the production units are likely to get closed in the short run. As a result, in hill and mountain agriculture where the rise in the labour productivity is very difficult under the technology being adopted, many farmers 
have abandoned the farmland particularly the marginal farmlands. Likewise, though the remittance generated through foreign employment has largely supported the national economy, the remittance per worker is low due to low level skill among migrants labourer. Skill trainings would enhance income and human capital.

\section{CONCLUSIONS}

Labour migration, poverty and agriculture growth are highly related in the economy. The labour migration has three phases based on the ratio of the labour migrated over the total labour force in the country. At the first phase of labour migration the ratio of the labour migrated is small and it has little effect on the productivity in the domestic economy. At the second phase of the labour migration, the ratio of migrated labour increases, the remittance from the labour migration reduces poverty and increases the productivity of the agriculture. This may be due to the increase in the productivity of the remaining labour force. But at the third phase of labour migration, it reduces poverty from the remittances and at the same time decreases agricultural production. We recommend for staying at the second stage of labour migration. It means, theoretically it appears that Nepal has entered into the third stage of labour migration and it can only benefit if it can attract some of the labour force back to its agriculture. This can be possible by technological interventions and farm business supports.

The policy makers in the country appear happy with the outcome that the labour migration to foreign countries generates remittance that benefits the households and the economy reducing the poverty. But, this is only one side of the effects of migration in the economy. We should learn that if the labour migration increases above a certain threshold level, it may harm the domestic production increasing import dependency and vulnerability.

We should come up with some policy about the regulation of the out migration for foreign employment to the benefits of the migrants and the economy aggregate. We should estimate the threshold of the labour migration and devise the migration policies accordingly. The migration can be encouraged till it takes away the surplus labour from the economy and increases labour productivity without creating labour scarcity in the domestic production. As the productivity of unskilled labour is hard to increase, the nation should go for massive labour training and technology adoption for domestic industries too. Utilization of the money from remittances for farm mechanization can increase the labour productivity back home. For regulating the labour out flow, we recommend market approaches such as policy of increasing labour productivity at the domestic industries, which can increase the domestic wage rate and ration the labour migration. For increasing the labour productivity in the domestic industries, particularly agriculture, policy consistency, market linkages, credit flow and business incubation supports are recommended along with the technological packages. 


\section{ACKNOWLEDGEMENT}

The author is thankful to the anonymous reviewers for their valuable comments and suggestions on the manuscript. He also acknowledges the supports of South Asian Network of Economic Research Institutions (SANEI) and its Research Advisory Panel (RAP) members in the study.

\section{REFERENCES}

Adams, R. H. 2003 International migration, remittances, and poverty in developing countries No 3179, Policy Research Working Paper Series from The World Bank

Adams, R. and J. Page 2005 Do international migration and remittances reduce poverty in developing countries? World Development 33 (October): 1645-1669.

Aigbokhan, B. E. and A. Alli 2008 Growth, Inequality and Poverty in Nigeria, ACGS/MPAMS Discussion Paper No.3 Prepared for United Nations Economic Commission for Africa (UNECA) Addis Ababa, Ethiopia.

CBS, 2004 National Living Standard Survey 2003/04, Main Report, Central Bureau of Statistics, Kathmandu.

CBS, 2006a Monograph: Agriculture Census Nepal 2001/02, National Planning Commission, Central Bureau of Statistics, Kathmandu.

CBS 2006b Resilience Amidst Conflict: an Assessment of Poverty in Nepal, 1995-96 and 2003-04, Kathmandu

CBS, 2009 Nepal Labour Force Survey 2008, Central Bureau of Statistics, Kathmandu, Kathmandu.

CBS, 2012 National Population and Housing Census 2011 (National Report), Central Bureau of Statistics, Kathmandu, Kathmandu.

Cornia, G.A. and S. Kiiski 2001 Trends in Income distribution in the post-World War II Period: Evidence and Interpretation, UNU-WIDER Discussion Paper No. 2001/89.

Dollar, D. and A. Kraay 2001 Growth is Good for the Poor. Policy Research Working Paper 2587, World Bank, Washington, D.C.

Government of Nepal 2011 Agricultural Development Strategy (ADS), Assessment Report, Kathmandu.

Hoermann, B., S. Banerjee and M. Kollmair 2010 Labour Migration for Development in the Western Hindu Kush-Himalayas Understanding a livelihood strategy in the context of socioeconomic and environmental change, International Centre for Integrated Mountain Development, Kathmandu.

ILO, 1996a Wage workers in agriculture: Conditions of employment and work. Report for discussion at the Tripartite Meeting on Improving the Conditions of Employment and Work of Agricultural Wage Workers in the Context of Economic Restructuring. ISBN 922-110126-6. International Labour Office, Geneva.

ILO, 1996b Agricultural Wage Workers: the Poorest of the Rural Poor ILO/96/26 Press release, 23 September 1996, International Labour Organization. http:// www.ilo.org/global/about-the-ilo/newsroom/news/WCMS_008067/lang--en/index.htm accessed on 02 March 2013.

Islam, I. 2002 Poverty, Employment and Wages: An Indonesian Perspective, in Labour Market Policies and Poverty Reduction Strategies in Recovery from the Asian Crisis. Report of a seminar held in Jakarta, 29 April - 1 May 2002. ILO, Bangkok.

Islam, R. 2004 The Nexus of Economic Growth, Employment and Poverty Reduction: An Empirical Analysis, Issues in Employment and Poverty, Discussion Paper 14, Recovery and Reconstruction Department International Labour Office, Geneva 
Kapsos, S. and Horne, R. 2011 Working poverty in the world: Introducing new estimates using household survey data, in ILO: Key Indicators of the Labour Market, $7^{\text {th }}$ edn (Geneva, ILO), Ch. 1A.

Khan, A. R. 2007 Growth, employment and poverty: An analysis of the vital nexus based on some recent UNDP and ILO/SIDA studies, DESA Working Paper No. 49, ST/ESA/2007/DWP/49, United Nations Department of Economic and Social Affairs, New York, http://www.un.org/esa/desa/papers, accessed on $12^{\text {th }}$ March 2009.

McKinley, T., J. Weeks, B. Khattry, R. Oktaviani, H. Saparini, J. Lim and B. Santoso 2003 Pro-Poor Macro Policies in Indonesia. UNDP Regional Project on the Macroeconomics of Poverty Reduction: Kathmandu.

Mellor, J. B. 1999 The Structure of Growth and Poverty Reduction, (Mimeo) World Bank, Washington D.C.

MOF, 2010 Economic Survey, Ministry of Finance, Kathmandu.

Osmani, S.R., W. Mahmud, B.Sen, H. Dagdeviren and A. Seth 2003 Macroeconomics of poverty reduction: The case of Bangladesh. Paper presented at a regional workshop on the Macroeconomics of Poverty Reduction organized by the UNDP, Kath., 4-6 Jan 2003.

Osmani, S. R. 2004 The Employment Nexus between Growth and Poverty: An Asian Perspective, A Report prepared for the Swedish International Development Agency (SIDA), Stockholm and the United Nations Development Programme (UNDP), New York.

Pant, B. 2008 Mobilizing Remittances for Productive Use, NRB Working Paper (Serial No: NRB/WP/4), Nepal Rastra Bank.

Rahman, R. I. and K. M. N. Islam 2003 Employment Poverty Linkages: The Case of Bangladesh. Issues in Employment and Poverty, Discussion Paper No. 10. Recovery and Reconstruction Department, International Labour Office: Geneva.

Ravallion, M. 2001 Growth, Inequality and Poverty: Looking Beyond Averages. World Development, vol. 29, no. 11.

Ravallion, M. and G. Datt 1996 How Important to India's Poor is the Sectoral Composition of Economic Growth? World Bank Economic Review 10, pp. 1-25.

Riester, A. 2010 Impact of the global recession on international labor migration and remittances: Implications for poverty reduction and development in Nepal, Philippines, Tajikistan, and Uzbekistan. In: Bauer A and M Thant (edts) (2010), Poverty and Sustainable Development in Asia: Impacts and Responses to the Global Economic Crisis, Asian Development Bank, Manila.

Seddon, D. 2005 Nepal's dependence on exporting labour. www.migrationinformation.org/

UN, 2005 The centrality of employment to poverty eradication, Report of the SecretaryGeneral to General Assembly, Sixtieth session, Item 58 (a) of the provisional agenda, Eradication of poverty and other development issues: Implementation of the first United Nations Decade for the Eradication of Poverty (1997-2006), USA

UNDP, 2003a Armenia, UNDP Regional Project on the Macroeconomics of Poverty Reduction: Kathmandu.

UNDP, 2003b Growth and Poverty Reduction in the Next Decade: A Report to the Government of Uzbekistan (mimeo.) UNDP Regional Project on the Macroeconomics of Poverty Reduction: Kathmandu.

Weeks, J., N. Thang, R. Roy and J. Lim 2003 Vietnam: Seeking Equity with Growth. UNDP Regional Project on the Macroeconomics of Poverty Reduction: Kathmandu.

World Bank, 2000 Attacking Poverty, World Development Report 2001/2002, New York, Oxford University Press. 